\title{
THE CANADIAN SOCIETY OF FOREST ENGINEERS ${ }^{1}$
}

\author{
By F. D. Mulholland, \\ Forest Engineer, Victoria, B.C
}

W

E ARE meeting for the second time under the shadow of this war which is being fought for the maintenance of our democratic way of life, in opposition to the organization of mankind by bullies; for the freedom of our democracy and of others which have fallen or are yet beyond the tyrant's reach.

Our first duty is to do our share in this war.

\section{THE SOCIETY AND THE WAR}

Early in the year the Society offered its services to the Government in whatever way it could assist the national war effort to best advantage. This action was approved by our Sections throughout Canada.

A special Committee of the Society at Ottawa was authorized to conduct a voluntary registration of our members in order to assist the Dominion Government in the selection of suitable personnel for such work as it might have for men of our training and experience. Including those who had previously registered, over $80 \%$ of our members thus signified their willingness to place themselves at the disposal of the Government for war service.

Later, hearing of the organization of a Canadian Forestry Corps, the President telegraphed the Minister of National Defence that the Society's membership included many men competent for commissions in this Corps, and asked for information.

With respect to men of our craft, the Government has been offered the services of many more than it has so far been able to use.

A few of our members are in the Forestry Corps; some are in His Majesty's Canadian and British Forces in the infantry, artillery, and engineers; some are on war work in connection with timber supply; a few Civil Servants have been transferred to other Services depleted by war enlistments.

But for the majority of our members it must be assumed that the Gov, ernment considers that they can serve best where they are.

Those employed in the great lumber and pulp industries are doing work necessary to the economic life of Canada.

Those employed in the production of timber for Great Britain and Empire war purposes are directly filling one of the essential requirements of war.

Those employed in the conservation of forest resources may also feel that they are supporting the country at war. The Prime Minister of Canada has said that "the safeguarding of forest resources, adequate to the country's needs, in time of war becomes a form of patriotism which no nation or people can afford to neglect."

1. Address of the Retiring President, delivered at the Thirty-third Annual Meeting of the Socicty, Victoria, B.C., February 6, 7, 8, 1941 . 
Those who are unemployed, or employed at work which seems unessential in war time, must wait until Canada's war effort is sufficiently intense to require their services at home or abroad; perhaps meanwhile they can comfort themselves with the thought that Canada is so richly supplied with skilled men that she can meet the requirements of war without making full use of the man-power at her disposal. Recent official statements indicate that the Government is increasing its war effort in several directions which may require additional skilled personnel, and undoubtedly preparations for postwar reconstruction will have to be made.

So far few Canadians of this generation have suffered the intimate acquaintance with the horrors of war which have become almost a commonplace for the people of our blood and beliefs in England and on the continent of Europe.

Democracy assumes a state of peace; war is not one of its objectives; it does not normally organize for war, so its maximum effort is slow in develop. ing. Meanwhile there is a responsibility upon those who stay at home to maintain the machinery of peaceful and democratic life, even though its wheels must move more slowly in war, lest the very things for which we are fighting are forgotten and lost.

Part of this machinery is the freedom and the influence of such associa. tions as this. In Germany they have been abolished; they embarrass that type of government; members of the professions must be subservient to the dictation of deranged individuals with a lust for power over their fellow men.

\section{Forest Publicity}

Many features of progress in forestry require public support. For many years Canadian foresters have sought to arouse public consciousness to the value of the forest resources and the necessity of proper administration and conservation. But the efforts of these evangelists have been uncoordinated and often confusing.

For example, a recent article in a lumber journal drew attention to the fact that $40 \%$ of the productive forest area of B.C. contains established immature stands, and predicted that the future would see our forest industries greatly expanded.

In contrast with this, a recent official address to the B.C. Legislature disregarded the annual increment in these young forests (which, after allow. ing for the average loss by fire, is estimated to be 1,600 million feet, about $40 \%$ already accessible) and stated that "we are on. a slippery slope which inevitably will reduce our forest resources to fence posts and pit-props."

A third statement, in a recent official report for the whole of Canada, said that "it would appear that there is sufficient timber of merchantable size to maintain the present annual cut and a reasonable amount of depletion from other causes until sufficient young growth attains merchantable size to meet the requirements."

Each of these opinions was expressed by a member of this Society.

Even so independent a body as the Rowell-Sirois Commission did not entirely unravel the thread of truth; for example, though most of us agree 
with its report that forest conservation has been seriously neglected, it also said, as our Editor has pointed out, that the white pine of the Ottawa Valley and New Brunswick, and the Douglas fir of B.C., are being exhausted and that their replacement is not practical.

Is silviculture so impossible in Canada?

This divergence of opinion, and even of factual statement, must make it difficult for legislators and the public to understand the forestry situation, and may be the reason why some authorities regard forest propaganda with suspicion.

The Government Services have been asked to give us their views and their objectives. I regret that the great Province of Ontario has been unable to submit even the briefest of statements. It is hard to believe that it has no forest policy or program.

Another Province believes that it should have a monopoly of forest propaganda, and has deprecated the existence of contrary publicity as probably having ulterior motives.

Let us face these facts. One Government Service is not allowed to speak; another wants to be the only speaker; two give opposing statements. I believe Government foresters themselves realize that this is not a satisfactory situation, and that assistance is needed.

The remedy for confusion of cries in the market-place is co-ordination of professional opinion beforehand, so that there may be harmony in public expression.

\section{The Society and Forest Policy}

In order to dispel this confusion and to co-ordinate these individual efforts, the Sections of this Society have for more than a year been studying forest conditions, forest policy and forest administration, with the object of reaching agreement as to what are the most important needs of Canadian forestry.

During the year a special committee or council of past-Presidents has been appointed to co-ordinate the recommendations of our Sections, considering also those of allied associations such as the Quebec Forest Engineers, the New Brunswick Foresters, the Canadian Forestry Association, Lumbermen's Associations, and other authorities, including of course the presentations of the Forest Services themselves. Here we should give credit to the Association of Forest Engineers of Quebec for its initiative in this matter. From this material this committee will attempt to formulate a Canadian Forest Policy which may meet with the approval of this Society's membership. When that has been obtained there will be a basis for uniform publicity on forestry as a national interest. Similar procedure may co-ordinate the opinions of those concerned with Provincial forestry problems, because the responsibility for forest administration lies on each Province, unless it should unfortunately happen that a Province, on account of financial disability or for some other reason, may need assistance in the administration of its natural resources to prevent serious harm to national economy.

The object of this committee is not to produce a text-book on forestry; nor a repetition of platitudes; nor a criticism of administrations or of industries; nor an ideal for someone else to achieve; but to state plainly the objectives 
of forestry and the practical steps by which, in the opinion of foresters and lumbermen, those objectives can effectively be pursued; the Society will then, by action as a corporate body, and by the work of its individual members, endeavour in harmony to implement its own proposals.

I ask every member to give sincere and unprejudiced assistance and support to this Committee.

\section{AfTer THE WAR}

It is generally agreed that there will be profound economic changes after the war, from the effect of which forest industries and foresters will not be immune. We should prepare for such changes. We are civilized men of initiative and culture, grown men able to condlict our own affairs, not children to be governed by coercion on the false "leadership principle," as exemplified by its arch exponent in Berlin. I do not think that anyone will advocate that all forest administration should be centralized at Ottawa. There is plenty of forestry work for the Dominion Government; the Sirois Commission, and this Society have suggested forest research as its chief field of activity. Decentralization is a principle of democratic administration, and it has been carried to great lengths with success in Scandinavian forestry. Some regulation is necessary, but, as Colonel Greeley, former Chief Forester of the United States, said at a recent meeting of the Society of American Foresters, "the best regulation is that which is closest to the people who are being regulated. If regulation starts with forest industry itself, it will be carried out more effectively than if ordered from Government agencies." Nor would it be an advantage to the profession for the industry of growing timber in managed forests to be a Government monopoly. State employment of a whole profession subjects its members to political and personal influences unrelated to efficiency and accomplishment.

The general record of Government forestry in Canada is not such as to justify exclusion of consideration of greater encouragement for private forestry, which has proved so successful in European democracies. The prob. lems of sustained yield are economic and industrial and should be solved by industrial rather than political action.

\section{Government Services Need Encouragement}

Meanwhile the Governments have taken the responsibility and they need encouragement. In Ontario they need encouragement to save their white pine from blister rust. In B.C., which the location of this meeting makes more interesting to most of you, they need encouragement in reforestation and protection from fire.

Although the first experimental nursery was established 15 years ago, B.C. has only been able to plant some 4,000 acres, a replacement of about $7 \%$ of a single year's cut on the coast. Owing to the foresight of the present Minister the Department now has a program of planting 12,000 acres annually beginning in a year or two. This will cost money which war conditions may make it difficult to obtain without much public support. The Society may wish to encourage this project.

The Forest Service has repeatedly reported that its funds for protection are inadequate; worse still, this year it informed the Legislature that it is not allowed to spend even these inadequate funds in the most effective manner. 
The Society may wish to support the Department here too.

\section{Put War Profits Back Into the Forest}

The war has created a boom in B.C. forest industry. Last year the value of production was a record of 100 million dollars. The increase in Government revenue has not yet been reported, but it may have reached a million dollars. We are making money from the necessities of the British, who are the chief importers of our products.

We are supplying material essential for war; we are compelled to deplete the coast forests just as the British sacrificed many long cherished woods during the last war; but should this extra revenue be used to improve our standard of living, while the people who pay us have theirs so disastrously lowered by bombs? The industries' share of this extra profit goes into our war effort through extra taxation. Should we suggest that the Government put back its share of the profit into the forest by more intensive protection and reforestation. Here is the money for which the Service has been pleading so long.

Protection and reforestation are merely a beginning on the way to sustained yield.

Excluding experimental areas, how many Government forests are being managed on a sustained yield basis? How many Canadian foresters are engaged in such management? Private enterprise in the pulp-industry accounts for a few; but the Forest Schools, having an eye on jobs for their graduates, do not think it worth while to give much prominence to the subject in their courses.

It is not much use to wait until economic conditions justify putting Canada's forests, as a whole, on a sustained yield plan. Such management must be built up step by step.

There is a very important place for the Society in war and in peace; its objects are practical and patriotic. Its success will be measured by the sum of what each individual puts into it, not by what he gets out of it.

You have heard the financial report; we cannot make bricks without straw; do you really think an increase in dues equivalent to $10 \mathrm{c}$ per week is too big for your share towards the support of your professional society and its objectives?

You have heard the report of the Editorial Board. How much are you interested in your publications? Have you contributed to them, even so much as a letter to the Editor?

I believe that, in this year of war, the Society has justified its existence; it is for its members to continue its life, to expand its usefulness and send it further along its road to the objective of sustained yield for Canadian forests, for the support of permanent forest industries, for continuous employment, for permanent prosperity based on well-managed forests.

A great philosopher said 25 centuries ago, "When you once try to think out a thing, you must never give it up until you have what you want; when you once try to carry out a thing, you must never give it up until you have done it thoroughly and well."

We undertook a job when we joined this Society. Let us see that we do it thoroughly and well. 